\title{
ESTUDOS QUÍMICOS, FÍSICOS E ISOTÓPICOS EM ZIRCÕES
}

\author{
L.A.Hartmann ${ }^{1}$, M.A.Z.Vasconcelos ${ }^{2}$, J.D.Leite ${ }^{3}$, L.Takehara ${ }^{3}$, M.V.D.Remus ${ }^{3}$, \\ M.T.F.Suita ${ }^{4}$, N.McNaughton ${ }^{3}$
}

Estudos químicos, físicos e isotópicos $\mathrm{U} / \mathrm{Pb}$ em zircões têm sido conduzidos pelos autores, com o objetivo inicial de entender a evolução geocronológica de alguns segmentos dos terrenos Pré-Cambrianos do Brasil, evoluindo para o entendimento dos processos químicos e fisicos envolvidos na recristalização de cristais complexos (Hartmann et al., 1995a,b; 1996a,b,c; Suita et al., 1994; Leite, 1995; Leite et al., 1995a,b; 1996; Remus et al., 1995, 1996; Takehara et al., 1996; Macambira et al., 1996; Porto Rosa \& Hartmann, 1996; Babinski et al., 1996). Alguns dos artigos internacionais utilizados como referência são os de Pupin, 1992; Vavra, 1990; Pidgeon, 1992; Paterson et al., 1992; Hanchar \& Miller, 1993; Hanchar \& Rudnick, 1995; Williams, 1992; Williams et al., 1995; Elburg, 1996.

Os problemas geológicos incluidos nos estudos são o Complexo de Barro Alto em Goiás (CBA), a Seqüência máfica-ultramáfica Cerro Mantiqueiras (SCM) e Complexo Cambai (Ccam) associado, o Complexo Encantadas (Cenc) na região de Caçapava do Sul e o Granito Caçapava (Gcaç) no Rio Grande do Sul. Essa diversidade abrange o magmatismo de pluma meso-proterozóico do CBA afetado por zonas de cisalhamento de fácies granulito, uma unidade Transamazônica (Cenc), uma região de acresção juvenil do Neoproterozóico (SCM, Ccam) e ainda um granito de refusão crustal (Gcaç).

A metodologia utilizada após o mapeamento geológico consistiu de separação dos zircões por métodos convencionais, seu estudo por espectrometria de massa convencional no Royal Ontario Museum do Canadá (CBA), por SHRIMP em Perth, Austrália (SCM, Ccam, Cenc, Gcaç). Após isso, foram realizados estudos de imagens de elétrons retro-espalhados (BSE), catodoluminescência (CL) e micro-análise eletrônica quantitativa (EPMA) no Laboratório de Microssonda Eletrônica/CPGq/IG/UFRGS.

Os estudos químicos mostram a distribuição interna no cristal de zircão dos elementos $\mathrm{Hf}, \mathrm{Y}, \mathrm{U}$, com sua zonação ígnea e redistribuição metamórfica. Os processos de difusão por transporte rápido e por difusão no retículo são identificados. Diagrama $\mathrm{Hf}, \mathrm{Y}, \mathrm{U}$ é discriminante de ambiente tectônico de geração dos magmas graníticos de acresção juvenil, póstectônico e de refusão crustal.

Os estudos físicos de BSE e CL mostram a presença de fraturas e eventual selamento, a formação de textura pseudo-ígnea por processos de difusão no retículo, e ainda a presença de inclusões de outros minerais, além da metamictização.

Os estudos isotópicos $\mathrm{U} / \mathrm{Pb}$ identificam a idade da pluma de manto primitivo do CBA como sendo no mínimo de $1,7 \mathrm{Ga}$ e o metamorfismo granulítico de $800 \mathrm{Ma}$. No sul do país, o Cenc representa o magmatismo de acresção juvenil de 2,45 Ga. 0 Ciclo Brasiliano mostra

\footnotetext{
${ }^{1}$ Instituto de Geociências, Universidade Federal do Rio Grande do Sul.

${ }^{2}$ Instituto de Física, Universidade Federal do Rio Grande do Sul.

${ }^{3}$ Pós-graduandos do Instituto de Geociências, Universidade Federal do Rio Grande do Sul.

${ }^{4}$ Universidade Federal de Ouro Preto.
} 
três eventos em $900 \mathrm{Ma}, 750 \mathrm{Ma}, 600 \mathrm{Ma}$, sendo os dois primeiros de acresção juvenil e o terceiro de retrabalhamento crustal.

O imageamento de BSE de 190 pontos analíticos SHRIMP em zircão mostra que $50 \%$ dos resultados não têm significado geológico, por caírem sobre fraturas ou inclusões não observados em microscopia ótica. As mesmas imagens permitem identificar a natureza do evento geológico datado, como sendo ígneo ou metamórfico.

\section{Referências Bibliográficas}

BABINSKI, M.; CHEMALE, F.; HARTMANN, L.A.; VAN SCHMUS, W.R.; SILVA, L.C. (1996) Juvenile accretion at 750-700 Ma in southern Brazil. Geology, v.24, n.5, p.439442.

ELBURG, M.A. (1996) U-Pb ages and morphologies of zircon in microgranitoid enclaves and peraluminous host granite: evidence for magma mingling. Contributions to Mineralogy and Petrology, v.123, p.177-189.

HANCHAR, J.M.; MILLER, C.F. (1993) Zircon zonation patterns as revealed by cathodoluminescence and backscattered electron images: Implications for interpretation of complex crustal histories. Chemical Geology, v.110, p.1-13.

HANCHAR, J.M.; RUDNICK, R.L. (1995) The application of cathodoluminescence and backscattered electron imaging to dating zircons from lower crustal xenoliths. Lithos, v.36, n.3/4, p.289-303.

HARTMANN, L.A.; VASCONCELOS, M.A.Z.; SUITA, M.T.F.; TAKEHARA, L.; CHEMALE JR., F. (1995a) Estudo integrado de zircão por microssonda eletrônica e espectrometria de massa: conseqüências geocronológicas. In: CONGRESSO BRASILEIRO DE GEOQUIIMICA, 5./CONGRESSO DE GEOQUÍMICA DOS PAÍSES DE LÍNGUA PORTUGUESA, 3., Niterói, 1995. Anais. Niterói, SBGq. (CD-ROM)

HARTMANN, L.A.; VASCONCELOS, M.A.Z.; TAKEHARA, L.; CHEMALE JR., F.; SUITA, M.T.F. (1995b) Datação U-Pb em zircão de rochas deformadas avaliada por estudos em microssonda eletrônica. In: SIMPÓSIO NACIONAL DE ESTUDOS TECTÔNICOS, 5., Gramado, 1995. Boletim de Resumos Expandidos. Porto Alegre, SBG/RS. p.385-386.

HARTMANN, L.A.; TAKEHARA, L.; LEITE, J.D.; McNAUGHTON, N.J. (no prelo) Fracture sealing in zircon evaluated by BSE imaging, EPMA and SHRIMP techniques. Chemical Geology.

HARTMANN, L.A.; VASCONCELOS, M.A.Z.; LEITE, J.D.; McNAUGHTON, N.J. (no prelo) Fine euhedral banding and younger core formation in zircon by fast-transport and lattice diffusion processes. Chemical Geology.

HARTMANN, L.A.; VASCONCELOS, M.A.Z.; SUITA, M.T.F. (no prelo) Zircon studies on the electron-microprobe: some geochronological implications. Geochimica Brasiliensis.

LEITE, J.D. (1995) Datação SHRIMP U/Pb em zircões e o exemplo de dois corpos graníticos contrastantes no Escudo Sul-riograndense. In: SIMPÓSIO SUL-BRASILEIRO DE GEOLOGIA, 6., Porto Alegre, 1995. Boletim de Resumos Expandidos. p.5-12.

LEITE, J.D.; McNAUGHTON, N.; HARTMANN, L.A.; CHEMALE JR., F. (1995a) Age and tectonic setting of metabasalts and metagranitoids from the Cerro Mantiqueiras region: evidences from SHRIMP U/Pb zircon dating and $\mathrm{Pb} / \mathrm{Pb}$ isotopes. In: SIMPOSIO NACIONAL DE ESTUDOS TECTÔNICOS, 5., Gramado, 1995. Boletim de Resumos Expandidos. Porto Alegre, SBG/RS. p.389-390.

LEITE, J.D.; McNAUGHTON, N.J.; HARTMANN, L.A.; CHEMALE JR., F.; REMUS, M.V.D. (1995b) SHRIMP U/Pb zircon dating applied to the determination of tectonic 
events: the example of the Caçapava do Sul Batholith, Pedreira Inducal, Caçapava do Sul, Brazil. In: SIMPÓSIO NACIONAL DE ESTUDOS TECTÔNICOS, 5., Gramado, 1995. Boletim de Resumos Expandidos. Porto Alegre, SBG/RS. p.387-388.

LEITE, J.D.; HARTMANN, L.A.; McNAUGHTON, N.J.; CHEMALE JR., F. (no prelo) Contrasting SHRIMP U/Pb isotopic evolution of zircon from Neoproterozoic juvenile and reworked terranes in Southernmost Brazil. Chemical Geology.

MACAMBIRA, M.J.B.; HARTMANN, L.A.; DALL'AGNOL, R. (1996) Zircão e granitogênese: resultados preliminares para os granitóides de Rio Maria, Província de Carajás - Pará. In: CONGRESSO BRASILEIRO DE GEOLOGIA, 39., Salvador, 1996. Anais. Salvador, SBG-BA, v.6, p.411-414.

PATERSON, B.A.; STEPHENS, W.E.; ROGERS, G.; WILLIAMS, I.S.; HINTON, R.W.; HERD, D.A. (1992) The nature of zircon inheritance in two granite plutons. Transactions of the Royal Society of Edinburgh: Earth Sciences, v.83, p.459-471.

PIDGEON, R.T. (1992) Recrystallization of oscillatory zoned zircon: some geochronological and petrological implications. Contributions to Mineralogy and Petrology, v.110, p.463472.

PORTO ROSA, A.; HARTMANN, L.A. (1996) Diagrama discriminante Hf, Y, U de zircão de granitóides de acresção juvenil, pós-tectônicos e de retrabalhamento crustal. Salão de Iniciação Científica CNPq, UFRGS.

PUPIN, J.P. (1992) Les zircons des granites océaniques et continentaux: couplage typologiegéochimie des éléments en traces. Bulletin Société Géologique de France, v.163, n.4, p.495-507.

REMUS, M.V.D.; McNAUGHTON, N.J.; HARTMANN, L.A.; GROVES, D.I. (1995) Oldest igneous rock in southern Brazil. In: AUSTRALIAN CONFERENCE GEOCHRONOLOGY AND ISOTOPE GEOSCIENCE, 3., Perth, 1995. Workshop Programs and Abstracts. Perth, p.29.

REMUS, M.V.D.; McNAUGHTON, N.J.; HARTMANN, L.A.; GROVES, D.I. (1996) SHRIMP U/Pb dating at $2448 \mathrm{Ma}$ of the oldest igneous rock in southern Brazil: identification of the westernmost border of the Dom Feliciano Belt. In: SYMPOSIUM ON ARCHEAN TERRANES OF THE SOUTH AMERICAN PLATFORM, 1996. Extended Abstracts p.67-70.

SUITA, M.T.F.; HARTMANN, L.A.; KAMO, S.L. (1994) The nature of high-grade Barro Alto layered mafic-ultramafic Complex and a discussion on the role of the Brasiliano/Uruaçuano Cycles in Goiás, Central Brazil. In: INTERNATIONAL SYMPOSIUM ON THE PHYSICAL AND CHEMISTRY OF THE UPPER MANTLE, São Paulo, 1994. Extended Abstracts p.82-83.

TAKEHARA, L.; HARTMANN, L.A.; VASCONCELOS, M.A.Z.; SUITA, M.T.F. (1996) Estudos de zonação em cristais de zircão do Complexo de Barro Alto (GO). In: CONGRESSO BRASILEIRO DE GEOLOGIA, 39., Salvador, 1996. Anais. Salvador, SBG-BA.

VAVRA, G. (1990) On the kinematics of zircon growth and its petrogenetic significance: a cathodoluminescence study. Contributions to Mineralogy and Petrology, v.106, p.90-99.

WILLIAMS, I.S. (1992) Some observations on the use of zircon U-Pb geochronology in the study of granitic rocks. Transactions of the Royal Society of Edinburgh: Earth Sciences, v.83, p.447-458.

WILLIAMS, I.S.; STOWE, S.; SHAH, J.S. (1995) Microbeam imaging of zircon growth structures. In: AUSTRALIAN CONFERENCE ON GEOCHRONOLOGY AND ISOTOPE GEOSCIENCE, 3., Perth, 1995. Workshop Programs and Abstract, Perth, p.42. 